Bangladesh J. Zool. 40(2): 221-229, 2012

\title{
AVAILABILITY OF VULNERABLE ELASMOBRANCHES IN THE MARINE WATER OF BANGLADESH
}

\author{
Roy Bikram Jit*, Nripendra Kumar Singha, S.M. Hasan Ali \\ and Md. Gaziur Rhaman \\ Marine Fisheries Survey Management Unit, C.G.O-2, 6 ${ }^{\text {th }}$ floor, Agrabad, \\ Chittagong, Bangladesh.
}

\begin{abstract}
A study was conducted about vulnerable shark and ray species availability and their percentage composition in two fish landing centers at Fishery ghat, Chittagong and BFDC fish harbor, Cox's Bazar district during April 2006 through March 2012. A total of 35 species (11 shark and 24 ray species) was identified within these six years. Out of 35 species, only one vulnerable shark species, the silky shark Carcharhinus falciformis (Muller and Henle, 1839), was not abundant all the year round and three were vulnerable ray species, Javanese cow ray Rhinoptera javanica (Muller and Henle, 1841), banded eagle ray Aetomylaeus nichofii (Bloch and Schneider, 1801) and white spotted shovelnose ray Rhynchobatus laevis (Bloch and Schneider 1801) were found throughout the year during the study period. The average percentage composition by weight of $C$. falciformis was 1.38 and the availability of average number was 3202. The average percentage contribution and the landed average number of vulnerable $R$. javanica, A. nichofii and R. laevis species were $1.46 \%$ (948 numbers), 0.61\% (554 numbers) and $0.54 \%$ (298 numbers), respectively of the total catch.

Key wards: Vulnerable elasmobranchs, percentage composition, total catch, abundance, sharks, rays.
\end{abstract}

\section{INTRODUCTION}

In Bangladesh marine fisheries consists of multi gear and multi species fishery. The industrial fishery or deep sea-trawling consisting of 177 commercial fishing trawlers and 43136 mechanized and non-mechanized boats are engaged in Artisanal fishing. As a single fishery shark and ray species are harvested commercially at artisanal fishing. And some small size (juveniles and new born) of sharks and rays are exploited by the trawl fishing which is not reported, because of low market value and less demand, thrown into the sea as a trash fish. Moreover, the catches of small size/juvenile sharks increased with the decrease of large size shark and some species are rare in the catches and some has entered into the IUCN threatened and endangered list (Haldar 2010).

The economic driving elasmobranch exploitation involves a paradox; sharks and rays have a relatively low economic value making them low priority resource when it comes to research or conservation, while the demand for some of their products, such as shark fins, is very high and simulates increased exploitation

*Author for correspondence. Email: jitroy1964@yahoo.com 
(Bonfil 1993). Shark fining practice of catching a shark, slicing off its fins and then discarding the body at sea, takes a tremendous toll on shark populations; up to 73 million sharks are killed every year to support primarily the global shark fin industry, valued for the Asian delicacy shark fin soup. The Northeast Atlantic chondrichthyan fauna is moderately diverse, with an estimated 118 species (approximately 11\% of total living chondrichthyans). Report of the IUCN shark specialist group-2006 shows that $26 \%$ of Northeast Atlantic chondrichthyans are threatened within the region (7\% critically endangered, $7 \%$ endangered, 12\% vulnerable). Globally, of the 1038 species of chondrichthyans assessed, $18 \%$ are threatened ( $3 \% \mathrm{CR}, 4 \% \mathrm{EN}$, and $11 \% \mathrm{VU}), 13 \%$ near threatened, 23\% least concern and 46\% data deficient (Gibson 2006). Oceanic pelagic sharks and rays are highly mobile species that are not associated closely with the sea floor and primarily live in the open ocean away from continental land masses. Many of them are especially vulnerable to over fishing because they have a slow rate of population growth (LFOPRS 2007). The commercial exploitation of sharks increased dramatically during the past 20 years all over the world. After worldwide dramatic increase in the exploitation of shark stocks, many shark populations are now believed to be endangered. There are indications that of the 100 exploited species, around 20 are vulnerable, endangered, or critically endangered (FAO 2009). C. falciformis is utilized for human consumption in various areas (Compagno 1984) and the record fishery training vessels in Japan indicates that $C$. falciformis has been utilized to some extent, which suggests that this species has some value to commercial long line vessels, too.

In this present study, effort has been made to determine the availability and percentage composition of vulnerable shark and ray species from April 2006 to March 2012 in Fishery ghat, Chittagong and BFDC fish harbor, Cox's Bazar. The main objective of this study was to find out the abundance of total sharks and rays, availability of vulnerable shark and ray species in the Bay of Bengal and their contribution to the total marine catch.

\section{MATERIAL AND METHODS}

'The survey work was carried out in Chittagong and Cox's Bazar districts of Bangladesh. Data were collected from two major fish landing centers which are located at i) Patarghata and Fishery ghat, Chittagong, and ii) BFDC fish Harbor in Cox's Bazar. Maximum sharks and rays caught are sold at these two landing centers. Data have been collected according to moon month in the period of new moon, full moon, 1st quarter and last quarter with field visits from April 2006 to March 2012 by Marine Fisheries Survey Management Unit (MFSMU), 
Chittagong. The primary data were assembled through field survey at the landing centers using a prescribed questionnaire by MFSMU. The questionnaire form was filled in by interviewing the organizers, aratdars (assembler) and fishermen directly from the field. All the collected data were analyzed and the shark and ray grouped were identified up to species level by using (i) Field guide to sharks, rays and chimeras of Malaysian and Neighboring countries; (ii) Field Identification Guide to the sharks and rays of the Red sea and Gulf of Aden; and (iii) FAO identification sheet and all the collected data were analyzed by the profiteer.

\section{RESULTS AND DISCUSSION}

A total of 11 species of shark and 24 species of ray was identified. Among them only one vulnerable shark species was silky shark Carcharhinus falciformis (Muller and Henle, 1839) and three vulnerable ray species were Javanese cow ray Rhinoptera javanica (Muller and Henle, 1841), banded eagle ray Aetomylaeus nichofii (Bloch and Schneider, 1801) and white spotted shovelnose ray Rhynchobatus laevis (Bloch and Schneider, 1801).

The landing trends of the vulnerable shark and ray species found in this study are presented in Table 1 . A total of 35 shark and ray species was available in our marine territory during April 2006 through 2012. Out of 35, 11 species belonged to shark and the rest 24 species to ray. Among the shark species, one (C. falciformis) is vulnerable; and among the ray species, three were $R$. javanica, $A$. nichofii and $R$. laevis which are vulnerable according to IUCN (2006).

During April 2006 through March 2007 total 399.788 MT sharks and rays were landed and total species number was 21. Among them, no vulnerable shark species was found. But, percentage composition by weight of landed vulnerable ray species $R$. javanica was $0.15 \%(0.619 \mathrm{MT})$ and total number of this species was $242 ; A$. nichofii $0.27 \%(1.060 \mathrm{MT})$ and total abundance was 400 and $R$. laevis was $0.69 \%(2.753 \mathrm{MT})$ and total number of the species landed was 567 (Table 1).

In the period between April 2007 and March 2008, total 21 species of shark and ray were found and their total weight was $211.532 \mathrm{MT}$; among them, the total weight of $C$. falciformis was 0.304 MT (0.14\%) and total number was 243. The percentage composition of $R$. javanica was $0.95 \%$ (2.007 MT), A. nichofii was $0.50 \%(1.068 \mathrm{MT})$ and $R$. laevis $0.39 \%(0.832)$ MT. The total number of abundance in $R$. javanica, A. nichofii and $R$. laevis were 803, 427 and 179, respectively. 


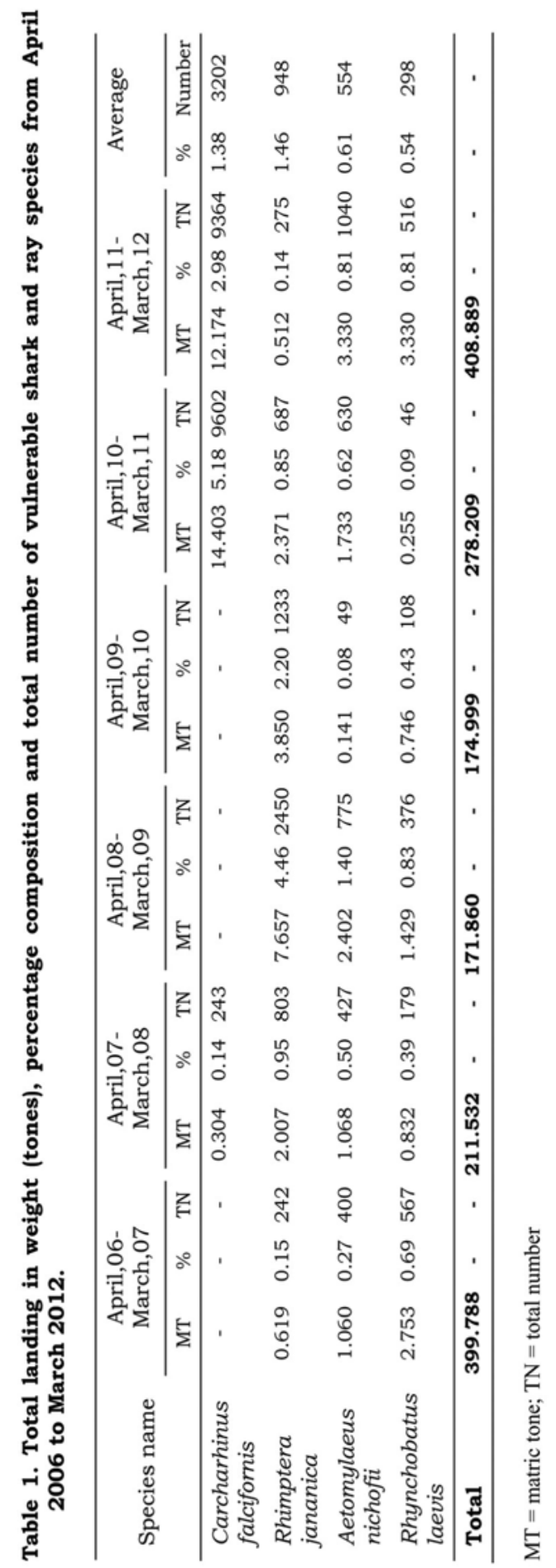


During 2008-2009, total 171.860 MT sharks and rays belonging to 20 species were landed, out of which no vulnerable shark species was found, but three vulnerable ray species was $R$. javanica $4.46 \%$ (7.657 MT), A. nechofii $1.40 \%$ $(2.402 \mathrm{MT})$ and $R$. laevis $0.8350 \%(1.429 \mathrm{MT})$, and the availability of total number of ray species was 2450 in $R$. javanica, 775 in A. nechofii and 376 in $R$. laevis.

In the period from April 2009 to March 2010, total 174.999 MT of shark and ray species (total 17) were landed. No vulnerable shark was found in this period. The percentage contributions of vulnerable ray species were $2.20 \%(3.850 \mathrm{MT})$ in $R$. javanica, $0.08 \%(0.141 \mathrm{MT})$ in $A$. nechofii and $0.43 \%(0.746 \mathrm{MT})$ in $R$. laevis. And total number of $R$. javanica, A. nechofii and $R$. laevis was 1233, 49 and 108, respectively.

During April 2010 through March 2011, 25 species of sharks and rays landed and their total weight was 278.209 MT. The percentage composition of vulnerable shark species was $5.18 \%(14.403 \mathrm{MT})$ in C. falciformis and total number of species was 9602 , vulnerable ray species was $0.85 \%(2.371 \mathrm{MT})$ in $R$. javanica followed by $0.62 \%(1.733 \mathrm{MT})$ in A. nichofii and $0.09 \%(0.255 \mathrm{MT})$ in $R$. laevis and total number of $R$. javanica was 687, A. nichofii was 630 and $R$. laevis was 46.

During April 2011 through March 2012, a total 26 of species of shark and ray was harvested and their total weight was 408.889 MT. Among them vulnerable shark species was C. falciformis whose percentage contribution was $2.98 \%(12.174 \mathrm{MT})$ and total landing number was 9364 and vulnerable ray species $R$. javanca was $0.14 \%$ (0.512 MT), A. nechofii $0.81 \%(3.333 \mathrm{MT})$ and $R$. laevis was $0.81 \%(3.330 \mathrm{MT})$ of the total catch, and the abundance of total number of $R$. javanca, A. nechofii and $R$. laevis was 275, 1040 and 516, respectively (Table 1$)$.

It was observed during the survey that a total of 35 shark and ray species was found in our marine territory from April 2006 to March 2012 and vulnerable shark species C. falciformis was not available in all the years, but three vulnerable ray species were available throughout the year. There are some shark and ray species that were available at least 5-10 years ago, but now they are endangered or vulnerable and their contribution to the total production is very low.

In the year 2010-2011 our total marine fish production was 0.55 million metric tons (M.MT) of which the shark fishery contributed only 4,205 MT $(0.77 \%)$ and account $0.14 \%$ of the total fish production of Bangladesh (DoF 2010-2011). In the present study, total catches were relatively low, averaging some 274 MT per year in the whole 2006-2012 period. But, in April 2011-March 
2012 they increased 409 MT and declining to some 172 MT and 174 MT in the following two years (2008-09 and 2009-10), respectively.

During the survey it was observed that some vulnerable species (IUCN 2000) were abundant and some were less abundant in the fish landing centers in Chittagong and Cox's Bazar districts. In the present six-year long investigation, 11 species of shark (viz. Scoliodon laticaudus, Rhizoprionodon acutus, R. oligolinx, Sphrna lewini, Chiloscyllicem indicum, Galeocerdo cuvier, Carcharhinus melanopterus, C. amblyrhynchoides, C. leucas, C. sorrah and C. falciformis) and 24 species of ray (viz. Himautura uarnak, $H$. fai, $H$. lobistoma, $H$. uarnacoides, $H$. gerrardi, H. undulata, H. walga, H. imbricata, Dasyatis zugii, D. kuhlii, Pastinachus sephen, Taeniura meyeni, Urogymnus asperrimus, Rhinobatos typus, R. thouin, Gymnura japanica, Aetomylaeus nichofii, Rhynachobatus laevis, Aetobatus narinari, Rhinoptera javanica, Rhina ancylostoma, Urogymnus asperrimus, Mobula kuhlii and M. japonica) were identified. Among them only four species of sharks and rays are vulnerable. The number of shark and ray species in Bangladesh reported by different authors varies. According to IUCN (2000) the total number was 56, while Hussain (1969), Day (1978), Quddus (1988), Roy (2006), Rahman (2009) and Roy (2011) mentioned the number as $56,63,21,22,51$ and 27, respectively. Cantor (1849) published a catalogue, which outlines the taxonomy of 28 species of sharks and rays in Malaysian waters, while Scott (1959) described some 294 marine fishes, out of which 25 are sharks and rays. About 70 species of sharks occur in Indian seas with which about 22 species have only limited occurrence and value, around 12 are moderately abundant though not frequently caught and only 6 are major in the fishery (Hanfee 1998).

Commercial and research operations for six areas of the Indian Ocean note that about 20 species of sharks occur in the bay catches, 11 of these sharks are common. Total commonly caught approximate mean weight was $590 \mathrm{~kg}$ and Carcharhinus falciformis contributed 10.17\% (Sivasubramaniam 1964). During 1983-85 catch composition data of Indian elasmobranch show that important batoids were Dicerobatus eregoodoo, Rhychobatus djiddensis, Rhinobatus granulatus, Himantura uarnak, H. bleekeri, Dasyatis jenkinsii, Aetobatus narinari, A. flagellum, Aetomylaeus nichofii and Mobula diabolus (Devadoss 1978). According to FAO (2000) Fishstat data, top 20 landed world catches of chondrichthyans species were 828364 MT, among them Carcharhinus falciformis contributed 16299 MT (1.97\%). Specieswise percentage contribution of total landing of sharks and rays at Chittagong and Cox's Bazar districts during April 2006 through June 2010 showed that among rays, the major contribution was by Himantura uarnak (120\%) followed by $H$. walga (60\%), $H$. 
bleekeri (34\%), Rhinobatos granulatus (18\%), Gymnura micrura (7\%), Mobula diabolus (11MT,5\%), Rhynchobatus djidensis (10MT, 5\%), Aetomylaeus nichofii (09MT, 4\%), Rhinoptera javanica (08MT, 4\%), and Narcine timlei (07MT, 4\%), and other species with least occurrence (08MT, 4\%). The species which were rare in the catch or constituted very low proportion are placed in other category (Roy 2011).

The study reveals that the average percentage composition and average number of vulnerable shark species C. falciformis availability was 3202 (1.38\%). But, from April 2010 to March 2011 their number increased sharply to 9602 (5.18\%); and during 2011-12 again decreased to 9364 (2.98\%). In the year 200708, shark population declined abruptly to only $243(0.14 \%)$ and it was totally absent during 2006-07 which followed in 2009-10 and 2010-2011. Totally absent of C. falcifomis during 2008-09 and 9-10 might be due to their late maturity, highly mobile and migratory characters; and harvesting of small sizes (juveniles) did not possible to renew the stock quickly like other bony fishes. The average percentage composition and average number of vulnerable ray species R. javanica was $1.46 \%$ and 948 , respectively and it increased gradually to $0.15 \%$ (242) and $0.95 \%$ (803) in the year 2006-07 and 2007-08, respectively, but sharply increased to $4.46 \%$ (2450) in 2008-09 and declined gradually to $2.20 \%$ (1233), $0.85 \%(687)$ and $0.14 \%$ (275) in the following years 2009-10, 2010-11 and 2011-12, respectively. The average percentage and number of $A$. nichofii was $0.61 \%$ (554) and it's abundance gradually increased to $0.27 \%$ (400), $0.50 \%(427)$ and $1.40 \%(775)$ during 2006-07, 07-08 and 08-09, respectively and declined sharply to $0.08 \%$ (49) in the year $09-10$ and again gradually increased to $0.62 \%$ (630) and $0.81 \%$ (1040) during 10-11 and 11-12, respectively. The average percentage contribution by $R$. laevis and its average number were 0.54 and 298, respectively; and it sharply declined to $0.09 \%$ and 46 , respectively during 2010 11 , but in other years the percentage composition fluctuated which was less than $1.0 \%$ of the total catch.

Major findings from this study are that the average weight of each landed $C$. falciformis was $1.339 \mathrm{~kg}$; and R. javanica, A. nichofii and $R$. laevis were 2.992, 2.928 and $5.227 \mathrm{~kg}$, respectively. In this study it is observed that the harvesting of shark fishery was over exploited and these vulnerable shark and ray species are harvested mainly in small sizes, but suddenly caught large in size with few numbers and their catch rates (catch per unit effort) reduce day by day. Total catch increased due to the increasing of active fishing days, number of fishing boats, gears; and new fishing techniques indicated that all shark and ray species were in fishing pressure. 
As human pressures increase many shark and ray populations have declined where they were once common. It is expected that the statistical interpretation would rightly focus on the status of vulnerable shark and ray species and contribute towards any national management plan for the shark fishery of Bangladesh.

\section{LITERATURE CITED}

BONFIL, R. and ABDALLAH, M. 2003. FAO Species Identification Guide for fishery purposes. Field Identification Guide to the Sharks and Rays of Red Sea and Gulf of Aden, Jeddah, Rome.

BONFIL, R. 1994. Overview of World elasmobranch fisheries. FAO Fisheries Technical paper 341, Instituto Nacional de la Pesca, Progreso, Yucatan, Mexico, 1.27, 106 pp.

CANTOR, T. 1849. Catalogue of Malaysia Fishes, J. Asiat. Soc. Beng. 18(2): 983.

COMPAGNO, L.J.V. 1984. FAO species catalogue, Vol. 4: Shark of the world; Part 2 Carcharhiniformis. Food and Agriculture Organization of the United Nations, Rome, Italy. 655 p.

DAY, F. 1978. The fishes of India Being a natural/history of the fishes known to in habit the Seas and Fresh water of India, Burma and Ceylon Vol. 1, Text New Delhi, pp. 730-740.

DEVADOSS, P. 1978. On the food of rays, Dasyatis uarnak, D. alcockii and D. sephen. Indian J. Fish. 25: 9-13.

DOF. 2010-2011. Fisheries Statistical Year Book of Bangladesh. Department of Fisheries, Matshya Bhaban, Dhaka, Bangladesh, 33 p.

FAO. 1994. Species Identification Sheets, fishing Area-51, FAO, Italy, Rome, 1-15 pp.

FAO. 2000. Fisheries Department, Fishery Information. Data and Statistics Unit, FISHSTAT plus: Universal Software for Fishery Statistical time Series. Version 2.3.

FAO. 2009. Food and Agriculture Organization. FAO concerned about severe declines in shark stockInternational Plan of Action calls for Sustainable Management, Rome.

GIBSON, C., VALENTI, S.V., FOWLER, S.L. and FORDHAM, S.V. 2006. The Conservation Status of Northeast Atlantic Chondrichthyans. Report of the IUCN Shark Specialist Group. Northeast Atlantic Regional red List Workshop. Peterborough, UK,13-15 February.

HALDAR, G.C. 2010. National Plan of Action for shark fisheries in Bangladesh. pp 75-89. In: Hussain, M.G. and Hoq, M.E. (eds). Sustainable Management of Fisheries Resources of the Bay of Bengal. Support to BOBLME project, Bangladesh Fisheries Research Institute, Bangladesh. $122 \mathrm{p}$.

HUSSAIN, M.M. 1969. Marine and Estuarine Fishes of North East part of the Bay of Bengal, Scientific Researches, East Regional Laboratories, Dhaka (Pakistan) Vol. VII (I): 502 p.

HANFEE, F. 1998. Management of Shark Fisheries in two Indian Coastal State: Tamil Nadu and Kerala, India.

IUCN (The World Conservation Union). 2000. Red book of threatened fishes of Bangladesh. IUCN Bangladesh Country office, House, 3A, Road 15 (new), Dhanmondi R/A, Dhaka-1209, Bangladesh, 116 p.

LFOPRS. 2007. Research Series: Global status of oceanic pelagic sharks and rays. Len Fest Ocean Program, December, Washington, D.C. (www.lenfestocean.org.). 
QUDDUS, M.M.A., SARKAR, M.N. and BANERJEE, A.K, 1988. Studies of the Chondrichthyes Fauna (sharks, skates and rays) of the Bay of Bengal. J. Noami 5(2): 19-23.

RAHMAN, A.K.A., KABIR, S.M.H., AHMAD, M., AHMAD, A.T.A., AHMAD, Z.U., BEGUM, Z.N.T, HUSSAN, M.A. and KHODKER, M. (eds.). 2009. Encyclopedia of Flora and Fauna of Bangladesh, Vol. 24. Marine Fishes, Asiatic Society of Bangladesh, Dhaka, 485 p.

ROY, B.J., DEY, M.P., ALAM, M.F. and SINGHA, N.K. 2007. Present status of shark fishing in the Marine water of Bangladesh, www.UNEP/CMS/MS/Inf/10.4 p.

ROY, B.J., ALAM, F.M., RHAMAN, G.M., SINGHA, N.K. and AKHTAR, A. 2011. Landing trends, species composition and Percentage contribution of sharks and rays in Chittagong and Cox's Bazar, Bangladesh. Bangladesh J. Marine Sci. Fish., Chittagong University, Chittagong, Bangladesh, Vol. 2.

SCOTT, J.S. 1959. An Introduction to the Sea fishes of Malaysia. Government press, Kuala Lumpur, $180 \mathrm{p}$

SIVASUBRAMANIAM, K. 1964. Predation of tuna logline catches in the Indian Ocean by killer whales and sharks. Bull. Fish. Res. Stn. Ceylon 17(2): 221-236.

(Manuscript received on September 9, 2012; revised on November 1, 2012) 